\title{
CONTROLLING ORGANISASI DALAM PERSPEKTIF AL-QUR'AN DAN HADITS
}

\author{
Endah Tri Wisudaningsih*
}

\begin{abstract}
Controlling, whether in terms of supervision or control by most societies, is often interpreted as an attempt by a manager or supervisory agency as an activity to find fault. In fact, if carefully understood, the function of supervision or control is actually as one of the strengths to make improvements if the results or services that have been standardized is not in accordance with the expected results. Standardization is one of the initial actions of the planning process and that standard must be reliable and reliable as a basis for evaluating and comparing through surveillance activities. Standardization of the planning process is intended for the achievement of organizational goals or effectiveness, while supervision is more focused on the implementation process and the results of productivity, both in the form of goods or services. Monitoring efforts should be maximized so that the business results of an organization is more efficient.
\end{abstract}

Keywords: Controlling, Organization, Qur'an, and Hadith

\section{A. Pendahuluan}

Controlling atau pengawasan merupakan salah satu aspek penting dalam dinamika sebuah organisasi, baik organisasi dalam bentuk perusahaan, pendidikan maupun yang lainnya. Selain sebagai bagian integral dari proses atau tahapan kinerja organsasi yang dimulai dari planning, organizing, actuating sampai controlling, dalam beberapa studi

\footnotetext{
* Dosen tetap Fakultas tarbiyah INZAH Genggong Kraksaan Probolinggo
} 
manajemen juga menunjukkan bahwa upaya pengawasan yang tereduksi dalam sebuah sistem kerja organisasi berpengaruh sangat signifikan terhadap peningkatan kinerja organisasi secara keseluruhan. ${ }^{1}$

Secara definitif, controlling dalam bahasa Indonesia dapat ditafsirkan sebagai pengawasan atau pengendalian, sehingga dalam bahasa Inggris pengertian pengawasan dan pengendalian tetap dipergunakan dengan istilah controlling. ${ }^{2}$ Istilah controlling dengan makna pengendalian atau pengawasan dalam konteks ilmu manajemen telah mengalami perkembangan definisi dari masa ke masa. Adapun yang cukup populer adalah pendapat Usury dan Hammer (1994:5) yang menyatakan bahwa: "Controlling is management's systematic efforts to achieve objectives by comparing performances to plan and taking appropriate action to correct important differences" (pengendalian adalah sebuah usaha sistematik dari manajemen untuk mencapai tujuan dengan membandingkan kinerja dengan rencana awal dan kemudian melakukan langkah perbaikan terhadap perbedaanperbedaan penting dari keduanya).

Berdasarkan pengertian di atas, dapat diketahui bahwa tujuan dari pengawasan atau pengendalian pada dasarnya adalah untuk menyesuaikan gerak organisasi yang sedang berlangsung dengan tujuan dan rencana awal (planning) dari organisasi itu sendiri. Dalam aspek ini, controlling memusatkan pada sisi efisiensi, sedangkan perencanaan atau planning lebih memusatkan pada sisi efektivitas. Walaupun di dalam proses pengendalian juga terdapat unsur efektivitas, namun secara fungsi bahwa upaya pengendalian lebih berpusat pada unsur efisiensi. Dengan demikian, controlling atau yang di dalam istilah Indonesia bermakna pengendalian, pengawasan atau kontrol, secara sederhana dapat diartikan sebagai suatu proses penyesuaian pergerakan antara organisasi dengan tujuannya.

Controlling, baik dalam pengertian pengawasan atau pengendalian oleh sebagian besar masyarakat sering ditafsirkan sebagai upaya seorang manajer atau lembaga pengawasan sebagai kegiatan untuk mencari

1 Anthony dan Vijay Govindarajan, Management Control System (Mc Clelland Grawhill: Ninth Eition, 1998), h. 28.

2 Hoetomo, Kamus Lengkap Babasa Indonesia (Surabaya: Mitra Pelajar, 2005), h. 219.

3 Buchari Alma, Majemen Pemasaran dan Pemasaran Jasa (Bandung: Alfabeta, 1992), h. 56. 
kesalahan. Padahal jika dipahami secara seksama, fungsi pengawasan atau pengendalian sesungguhnya adalah sebagai salah satu kekuatan untuk mengadakan perbaikan bila hasil atau jasa yang sudah distandarisasi itu tidak sesuai dengan hasil yang diharapkan. Standarisiasi merupakan salah satu tindakan awal dari proses perencanaan dan standar itu harus terandalkan dan dapat dipercayai sebagai dasar untuk mengevaluasi dan membandingkan melalui kegiatan pengawasan. Standarisasi dari proses perencanaan ditujukan untuk pencapaian sasaran atau efektifitas organisasi, sedangkan pengawasan lebih difokuskan pada proses pelaksanaan dan hasil dari produktifitas, baik yang berupa barang ataupun jasa. Upaya pengawasan harus dimaksimalkan agar hasil usaha dari suatu organisasi itu lebih efisien. ${ }^{4}$

Secara spesifik, fungsi controlling dalam aktivitas sebuah organisasi, di antaranya adalah: (1) meningkatkan akuntabilitas; (2) merangsang kepatuhan pada kebijakan, rencana, prosedur, peraturan, dan ketentuan yang berlaku; (3) melindungi aset organisasi; dan (4) pencapaian kegiatan yang ekonomis dan efisien. ${ }^{5}$ Fungsi pengawasan ini akan dapat dilakukan dengan maksimal, apabila dalam proses pelaksanaannya tetap berpegang pada azas-azas fundamental dari upaya pengawasan tersebut. Adapun azas-azas dari pengawasan atau pengendalian yang dimaksud adalah efektivitas, efiesiensi, kejujuran, transparansi dan tindakan korektif. ${ }^{6}$ Kesemua aspek fungsi yang disertai azas-azas dalam proses controlling ini menunjukkan bahwa upaya pengawasan dalam kegiatan organisasi menempati posisi yang sangat penting, agar setiap produk apapun yang dihasilkan menjadi lebih berkualitas dan tujuan yang telah ditetapkan dapat tercapai secara maksimal.

Dalam tahap implementasinya, pelaksanaan controlling juga perlu memperhatikan beberapa persyaratan atau prinsip-prinsip penting yang dapat memperkuat posisinya sesuai fungsi yang diharapkan. Persyaratan atau prinsip-prinsip yang dimaksud, di antaranya adalah: (1) Telah terencana dengan matang; (2) Memiliki Prosedur Operasional Standar (Standard Operational Procedur); (3) Dijalankan oleh orang yang amanah dan

4 M. Dale, Developing Management Skill (terjemahan) (Jakarta: Gramedia, 2003), h. $80-81$.

5 Buchari Alma, Manajemen ..., h. 57.

${ }^{6}$ Ibid.. 
berkapasitas (competence); (4) Akuntabel/transparan dan tertulis; (5) Efisien dalam penggunaan anggaran. ${ }^{7}$ Jika prinsip-prinsip ini telah dimiliki oleh setiap organisasi dalam aktivitas pengawasan yang dijalankan, setidaknya akan dapat memiminimalisir segala bentuk permasalahan yang terjadi di lapangan.

Melalui prinsip-prinsip pengawasan di atas, maka upaya pengawasan atau pengendalian perlu dilakukan secara maksimal oleh unsur-unsur yang terkait dalam sebuah organisasi. Dalam teori manajemen modern, terdapat beberapa teori yang menjelaskan tentang langkah-langkah dalam proses pengawasan. Di antaranya menurut Kadarman bahwa langkah-langkah pengawasan terdiri atas: (1) Menetapkan Standar, yang dilakukan dari proses perencanaan; (2) Mengukur Kinerja, yakni mengukur atau mengevaluasi kinerja yang dicapai terhadap standar yang telah ditentukan; (3) Memperbaiki Penyimpangan, karena proses pengawasan tidak akan lengkap jika tidak ada tindakan perbaikan terhadap penyimpangan-penyimpangan yang terjadi. Adapun elemen yang diperlukan dalam proses pengawasan ini adalah: (1) Detektor, alat/ petugas untuk mengidentifikasi apa yang sedang terjadi dalam suatu kegiatan; (2) Assesor, yaitu alat/petugas untuk menentukan ketepatan kerja; (3) Efektor, yaitu alat/petugas yang digunakan untuk mengubah sesuatu yang diperoleh dari assesor; (4) Jaringan komunikasi, yaitu alat/ petugas untuk mengirim informasi antara detektor dan assesor. ${ }^{8}$

Berdasarkan uraian di atas, maka secara umum dapat dipahami bahwa suatu organisasi yang dalam aspek kegiatannya terus bergerak dan semakin kompleks dari waktu ke waktu dengan banyaknya sumber daya yang ada sangat memungkinkan berbuat kesalahan atau menyimpang dari tujuannya. Guna mengevaluasi atas hasil kegiatan yang telah dilakukan, membuat fungsi pengawasan semakin penting kedudukannya dalam setiap organisasi. Tanpa adanya pengawasan yang baik, bisa jadi tujuan yang hendak dicapai akan kurang maksimal, baik bagi organisasinya itu sendiri maupun bagi sumber daya manusia yang ada di dalamnya.

Adapun penjelasan konsep controlling yang berangkat dari teori-

7 Edward Sallis, Total Quality Management in Education (Manajemen Mutu Pendidikan), terj. Ahmad Ali Riyadi \& Fahrurrozi (Yogyakarta: IRCiSoD, 2011), h. 58 .

8 Ibid., h. 59. 
teori umum di atas, merupakan konsep pengawasan yang secara praktis dilaksanakan dalam dunia manajemen-organisasi dewasa ini. Apabila dikaitkan dengan kajian keislaman, maka konsep pengawasan (controlling) yang diaktualisasikan dalam aktivitas organisasi kiranya perlu digali dari sumber utama, yakni al-Qur'an sebagai representasi pesan-pesan Tuhan yang ditujukan untuk menjadi pedoman (al-Huda) bagi umat manusia, serta al-Hadits yang bersumber dari Rasul-Nya. Hal ini perlu dilakukan agar prinsip-prinsip umum dan pesan-pesan penting yang terdapat dalam al-Qur'an dan al-Hadits dapat menjadi landasan nilai atau bahkan konsep yang aplikatif bagi setiap aktivitas dalam kehidupan manusia, terutama pada aspek keorganisasian atau manajemen pendidikan.

\section{B. Pembahasan}

\section{Terma Sebagian Ayat Al-Qur'an tentang Controlling}

Controlling atau pengawasan di dalam bahasa Arab memiliki makna yang sama dengan kata ar-Riqobah. Di dalam al-Qur'an, kata ini disebutkan pada beberapa ayat yang secara umum menunjukkan tentang adanya fungsi pengawasan, terutama pengawasan dari Allah swt. Ayatayat tersebut di antaranya adalah:

a. QS. An-Nisa [4]: 1

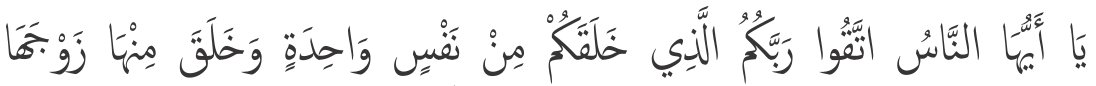

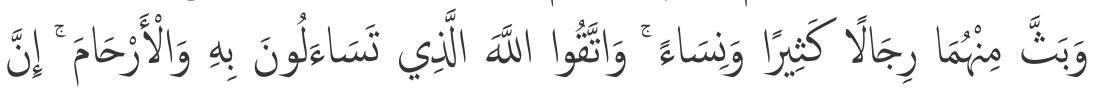

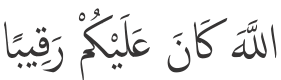

Artinya:"Hai sekalian manusia, bertakwalab kepada Tuhan-mu yang telab menciptakan kamu dari seorang diri, dan dari padanya Allah menciptakan isterinya; dan dari pada keduanya Allah memperkembang biakkan laki-laki dan perempuan yang banyak. Dan bertakwalab kepada Allah yang dengan (mempergunakan) nama-Nya kamu saling meminta satu sama lain dan (pelibaralab) bubungan silaturrabim. Sesunggubnya Allah selalu menjaga dan mengawasi kamu."

9 Lihat QS. an-Nisa' [4]: 1 
b. QS. Al-Maidah [5]: 117

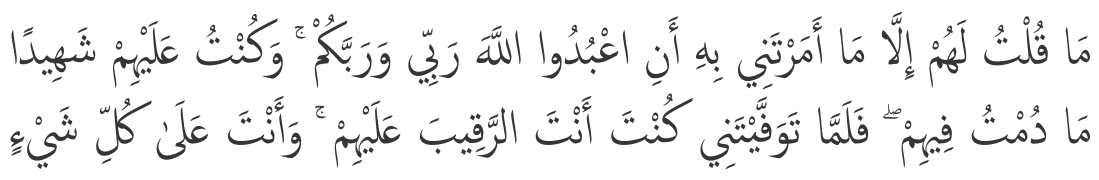

شَهِيْد

Artinya: "Aku tidak pernab mengatakan kepada mereka kecuali apa yang Engkau perintabkan kepadaku (mengatakan) nya yaitu: "Sembablah Allah, Tubanku dan Tubanmu", dan adalah aku menjadi saksi terbadap mereka, selama aku berada di antara mereka. Maka setelah Engkau wafatkan aku, Engkau-lah yang mengawasi mereka. Dan Engkau adalab Maha Menyaksikan atas segala sesuatu." 10

c. QS. Asy-Syura [26]: 6

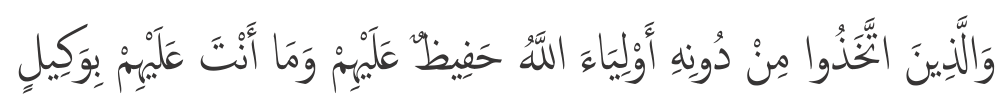

Artinya: "Sunggub mereka telah mendustakan (al-Qur'an), maka kelak akan datang kepada mereka (kenyataan dari) berita-berita yang selalu mereka perolok-olokkan."11

\section{Bahasan Tematik}

\section{a. Hakikat Controlling}

Dalam hadis shohih disebutkan: اعبد الله كأنك تراه , فإن لم تكن تراه فإنه يراك beribadahlah kepada Alloh seakan akan engkau melihatnya, jika engkau tak melihatnya maka sesungguhnya Alloh melihatmu. Ini merupakan petunjuk dan perintah tentang muroqobah pada al-Roqiib. ${ }^{12}$

Berkenaan dengan makna dari controlling, dalam beberapa literatur kajian Islam, sebenarnya telah dirumuskan beberapa konsep yang salah satunya dapat dirujuk dari pendapat Ahmad Bin Daud ${ }^{13}$ yang menyatakan

\footnotetext{
${ }^{10}$ Lihat QS. al-Maidah [5]: 117

${ }^{11}$ Lihat QS. asy-Syura [26]: 6

${ }^{12}$ Tafsir Ibnu Katsir

${ }^{13}$ Ahmad Bin Daud al-Mazjaji al-Asy'ari, "Muqoddimah Fi al-Idaroh alIslamiyah”, Jeddah, 2000,hlm: 346.
} 
bahwa: ${ }^{1415}$

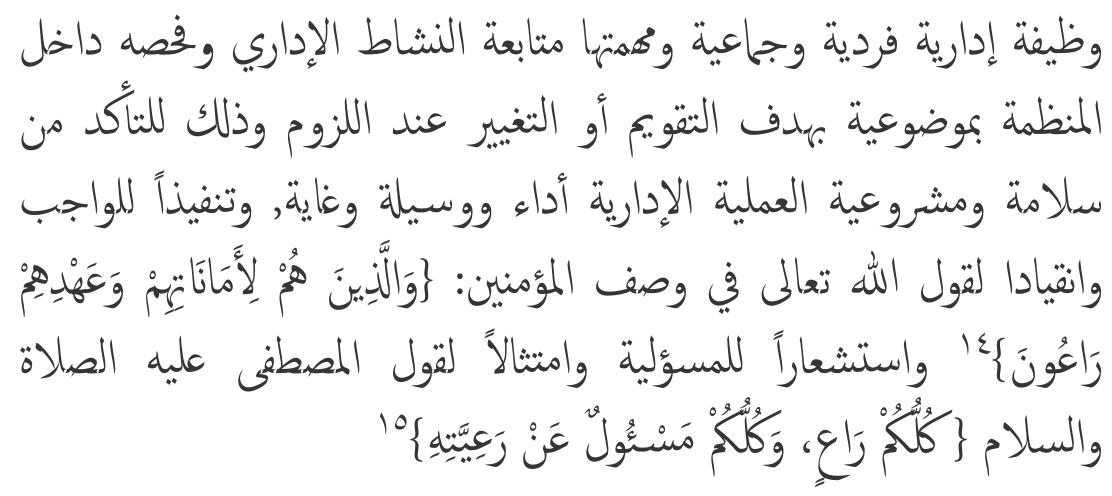

"Controlling adalah tugas administratif secara personal atau kolektif yang fokusnya adalah pemantauan aktifitas organisasi dan memeriksa kegiatan tersebut dari dalam sistem secara tematis (bagian per-bagian) dengan tujuan membetulkan yang salah atau mengubah sesuatu agar kembali kepada yang lazim (semestinya) dan yang demikian itu untuk memastikan akan keselamatan program kegiatan organisasi tersebut, baik dari segi pelaksanaan, sarana maupun tujuannya dan semua itu dilaksanakan dengan landasan melaksanakan kewajiban dan menaati firman Allah swt, yang berkenaan dengan penyifatan orang yang beriman: "Dan orang-orang yang memelibara amanab-amanab (yang dipikulnya) dan janjinya", dan sebagai bentuk rasa pertanggung jawaban serta pelaksanaan atas sabda Rosulullah saw: "Setiap kalian adalab pemimpin dan setiap kalian akan dimintai pertanggung jawaban atas kepemimpinannya tersebut"."

Dari penjelasan ayat dan definisi di atas, maka hakikat controlling atau pengawasan dalam Islam mempunyai karakteristik antara lain: pengawasan bersifat material dan spiritual, monitoring bukan hanya manajer, tetapi juga Allah Swt, menggunakan metode yang manusiawi yang menjunjung martabat manusia. Dalam konteks organisasi, ar-riqobah atau pengawasan merupakan kewajiban yang terus menerus harus dilaksanakan, karena pengawasan merupakan pengecekan jalannya

${ }^{14}$ Al-Qur'an. QS. al-Mukminun [23]: 8.

${ }^{15}$ Muhammad Bin Isma'il Bin Ibrohim Bin al-Mughiroh al-Bukhori. "Shohih al-Bukhori” no. Hadits 893 Bairut, hlm: 252. Dan Abu al-Husain Muslim Bin alHajjaj Bin Muslim al-Qusyoiri al-Naisyaburi. "Shohih Muslim" no. Hadits 3414, Bairut, hlm: 1623. 
planning dalam organisasi untuk menghindari kegagalan atau akibat yang lebih buruk. Mengenai faktor ini, al-Qur'an memberikan konsepsi yang tegas agar hal yang bersifat merugikan tidak terjadi. Tekanan alQur'an lebih dahulu pada intropeksi dan evaluasi diri dari pribadi seorang pemimpin apakah sudah sejalan dengan pola dan tingkah berdasarkan planning dan program yang telah dirumuskan semula.

\section{b. Fungsi dan Tujuan Controlling}

Di dalam al-Qur'an, fungsi pengawasan dapat terungkap di antaranya pada QS. as-Shof [61]: 3:

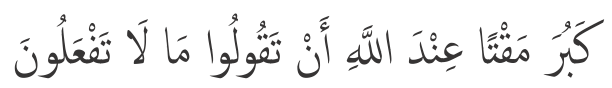

Artinya: "Amat besar kebencian di sisi Allah babwa kamu mengatakan apa-apa yang tidak kamu kerjakan."16

Ayat tersebut memberikan ancaman dan peringatan terhadap orang yang mengabaikan pengawasan terhadap perbuatannya. Selain ayat tersebut, terdapat beberapa ayat yang menjelaskan tentang pengawasan antara lain dalam QS. al-Sajdah [32]: 5 berikut:

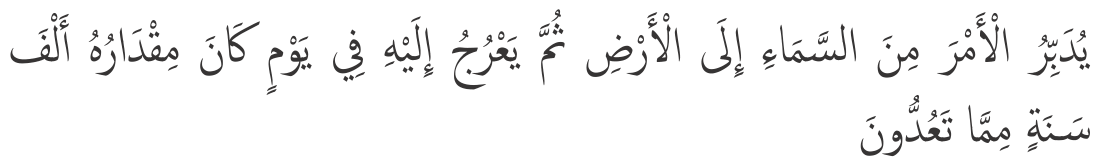

Artinya: "Dia mengatur urusan dari langit ke bumi, kemudian (urusan) itu naik kepada-Nya dalam satu hari yang kadarnya adalah seribu tabun menurut perbitunganmu."17

Kandungan ayat di atas menjelaskan bahwa Allah SWT adalah pengatur alam. Keteraturan alam raya ini, merupakan bukti kebesaran Allah swt dalam mengelola alam ini. Namun, karena manusia yang diciptakan Allah SWT telah dijadikan sebagai khalifah di bumi, maka dia harus mengatur dan mengelola bumi dengan sebaik-baiknya sebagaimana Allah mengatur alam raya ini. ${ }^{18}$

${ }^{16}$ Lihat QS. ash-Shof [61]: 3

${ }^{17}$ Lihat QS. as-Sajadh [32]: 5

${ }^{18}$ M. Quraish shihab, Tafsir Al-Misbah (Pesan, Kesan, dan Keserasian Al-Qur'an) (Jakarta: Lentera Hati, 2002), h. 120. 
Sejalan dengan kandungan ayat tersebut, manajemen merupakan sebuah proses pemanfaatan semua sumber daya melalui bantuan orang lain dan bekerjasama dengannya, agar tujuan bersama bisa dicapai secara efektif, efesien, dan produktif. Fungsi manajemen adalah merancang, mengorganisasikan, memerintah, mengoordinasi, dan mengendalikan. Selanjutnya Allah Swt memberi arahan kepada setiap orang yang beriman untuk mendesain rencana apa yang akan dilakukan dikemudian hari, sebagaimana Firman-Nya dalam QS. al-Hasyr [59]: 18 yang berbunyi:

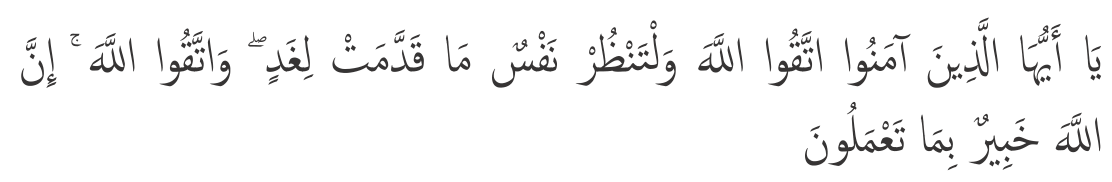

Artinya: "Hai orang-orang yang beriman, bertakwalab kepada Allab dan bendaklah setiap diri memperbatikan apa yang telab diperbuatnya untuk hari esok (akhirat); dan bertakwalah kepada Allah, sesunggubnya Allah Maba Mengetahui apa yang kamu kerjakan." 19

Beberapa hadits Rasulullah Saw juga menganjurkan perlunya melaksanakan pengawasan atau evaluasi dalam setiap pekerjaan. Ajaran Islam sangat memperhatikan adanya bentuk pengawasan terhadap diri terlebih dahulu sebelum melakukan pengawasan terhadap orang lain. Hal ini antara lain berdasarkan hadits Rasulullah Saw sebagai berikut:

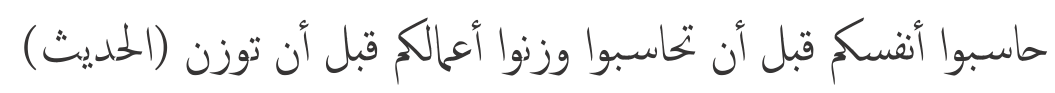

Artinya: "Periksalah dirimu sebelum memeriksa orang lain. Libatlah terlebih dabulu atas kerjamu sebelum melibat kerja orang lain." (HR. Tirmidzi: 2383).

Dalam pandangan Islam segala sesuatu harus dilakukan secara terencana, dan teratur. Tidak terkecuali dengan proses kegiatan belajarmengajar yang merupakan hal yang harus diperhatikan, karena substansi dari pembelajaran adalah membantu siswa agar mereka dapat belajar secara baik dan maksimal. Manajemen dalam hal ini berarti mengatur atau mengelola sesuatu hal agar menjadi baik. Hal ini sesuai dengan hadits, An-Nawawi (1987: 17) yang diriwayatkan dari Ya'la Rasulullah bersabda:

${ }^{19}$ Lihat QS. al-Hasyr [59]: 18 


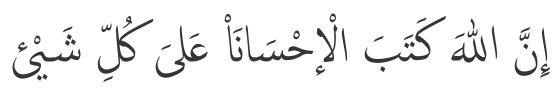

Artinya: "Sesunggubnya Allab mewajibkan kepada kita untuk berlaku ibsan dalam segala sesuatu." (HR. Bukhari) $)^{20}$

Berdasarkan hadits di atas, pengawasan dalam Islam dilakukan untuk meluruskan yang bengkok, mengoreksi yang salah dan membenarkan yang hak. Pengawasan di dalam ajaran Islam, paling tidak terbagi kepada 2 (dua) hal: pertama, pengawasan yang berasal dari diri, yang bersumber dari tauhid dan keimanan kepada Allah SWT. Orang yang yakin bahwa Allah pasti mengawasi hamba-Nya, maka orang itu akan bertindak hatihati. Ketika sendiri, dia yakin Allah yang kedua, dan ketika berdua dia yakin Allah yang ketiga. Allah SWT berfirman:

Artinya: "Tidaklab kamu perhatikan, babwa sesunggubnya Allab mengetabui apa yang ada di langit dan apa yang ada di bumi? Tiada pembicaraan rabasia antara tiga orang, melainkan Dia-lab yang keempatnya. Dan tiada (pembicaraan antara) lima melainkan Dia-lah yang keempatnya. Dan tiada (pembicaraan antara) lima orang, melainkan Dia-lah yang keenamnya. Dan tiada (pula) pembicaraan antara (jumlab) yang kurang dari itu atau lebih banyak, melainkan Dia ada bersama mereka di manapun mereka berada. Kemudian Dia akan memberitakan kepada mereka pada hari kiamat apa yang telab mereka kerjakan. Sesunggubnya Allab Maha Mengetahui segala sesuatu." (QS. al-Mujadalah [58]: 7).

Selain itu, berdasarkan hadits yang diriwayatkan oleh Imam Thabrani bahwasanya Rasulullah SAW bersabda:

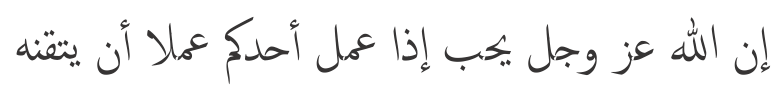

"Sesunggubnya Allab mencintai orang yang jika melakukan suatu pekerjaan, dilakukan secara itqan (tepat, terarah, dan tuntas)" (HR. Thabrani)

Tujuan melakukan pengawasan, pengendalian dan koreksi adalah untuk mencegah seseorang jatuh terjerumus kepada sesuatu yang salah. Tujuan lainnya adalah agar kualitas kehidupan terus meningkat. Inilah yang dimaksud dengan tausiyah, dan bukan untuk menjatuhkan. Fungsi manajerial pengawasan adalah untuk mengukur dan mengkoreksi kerja

${ }^{20}$ Muhammad Bin Isma'il Bin Ibrohim Bin al-Mughiroh Al-Bukhori, Shobih al-Bukhori. Bairu:Dar Ibnu Katsir al-Yamamah, No. 6010. 
bawahan untuk memastikan bahwa tujuan organisasi dan rencana yang didesain sedang dilaksanakan. Dalam konteks ini, implementasi syariah diwujudkan melalui tiga pilar pengawasan, yaitu: 1) ketaqwaan individu, bahwa seluruh personel perusahaan dipastikan dan dibina agar menjadi manusia yang bertaqwa; 2) pengawasan anggota, dalam suasana organisasi yang mencerminkan sebuah team maka proses keberlangsungan organisasi selalu akan mendapatkan pengawasan dari personelnya sesuai dengan arah yang telah ditetapkan; 3) Penerapan/supremasi aturan, organisasi ditegakkan dengan aturan main yang jelas dan transparan dan tidak bertentangan dengan syariah. ${ }^{21}$

Dari penjelasan di atas maka dapat ditegaskan bahwa pengawasan sebagai upaya pengecekan atas jalannya perencanaan (planning) dalam organisasi untuk menghindari kegagalan atau akibat yang lebih buruk. Mengenai faktor ini, al-Qur'an memberikan konsepsi yang tegas agar hal yang bersifat merugikan tidak terjadi. Tekanan al-Qur'an lebih dahulu pada intropeksi, evaluasi diri pribadi sebagai pimpinan apakah sudah sejalan dengan pola dan tingkah berdasarkan planning dan program yang telah dirumuskan semula. Setidak-tidaknya menunjukkan sikap yang simpatik dalam menjalankan tugas, selanjutnya mengadakan pengecekan atau memeriksa kerja anggotanya.

\section{c. Syarat Controlling}

Setelah diulas mengenai konsep controlling berdasarkan al-Qur'an dan hadits, berikut ini dibahas tentang syarat-syarat atas orang yang melakukan kontrol, yaitu:

1) Islam

Seorang manajer yang melakukan kontrol itu harus seorang muslim. Hal ini didasarkan pada firman Allah swt berikut ini: ${ }^{2223}$

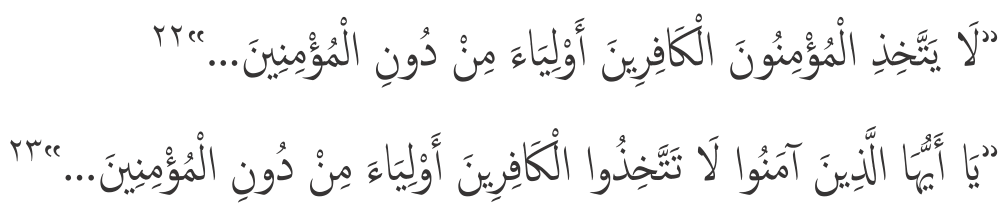

${ }^{21}$ Asy Syaikh Muhammad Bin Shalih Al-Utsaimin, Ulasan Kitab Hadits...”, h. 28.

${ }^{22}$ Al-Qur'an. QS. Ali Imron/ 3: 28

${ }^{23}$ Al-Qur'an. QS. An-Nisa ' / 4: 144 


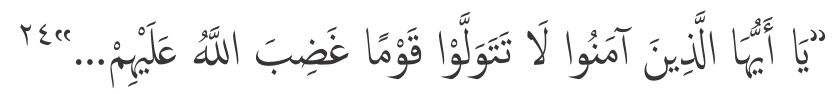

2) Berakal sehat, normal atau waras. (Maturity, الرشبد)

Seorang manajer yang melakukan kontrol itu harus berakal sehat dan tidak terganggu pikirannya oleh sebuah penyakit yang dapat mempengaruhi keputusannya. Hal ini didasarkan pada hadits Nabi saw berikut: ${ }^{2425}$

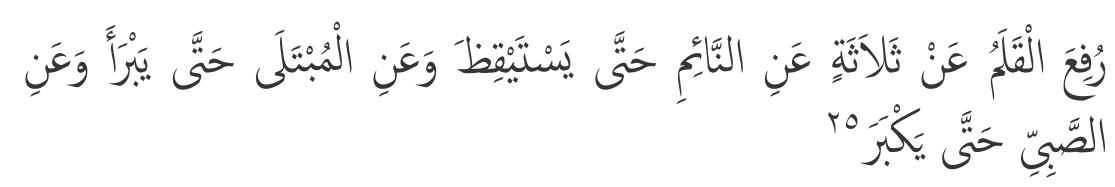

Artinya: Pena itu diangkat atas tiga: orang tidur sebingga bangun, orang teruji sehingga bebas dan anak sehingga dewasa.

3) Berpengetahuan (Knowladge, العلم)

Seorang manajer yang melakukan control itu harus berpengetahuan tentang persoalan manajerial, perihal kontrol dan cara yang benar dalam melaksanakannya. Hal ini dapat disimpulkan dari pemahaman terhadap firman Allah swt. ${ }^{26}$

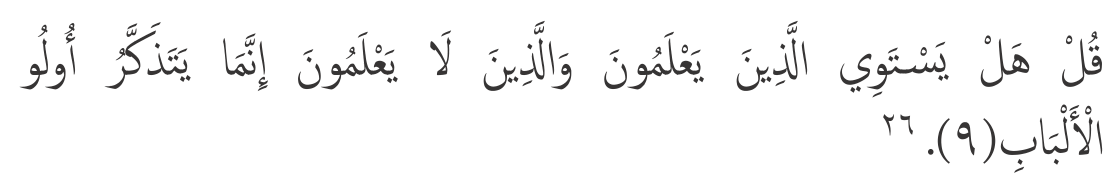

Dalam ayat tersebut, Allah swt menegaskan bahwa ada perbedaan yang sangat jelas antara orang yang berpengetahuan dengan yang tidak berpengetahuan. Hal ini dapat ditarik pemahaman lebih jauh dalam perihal kegiatan controlling, bahwa kebijakan seorang manajer yang berpengetahuan dengan yang tidak berpengetahuan akan sangat berbeda jauh. Oleh karena itu syarat berpengetahuan adalah sebuah keniscayaan.

4) Kemampuan (ability, القدرة)

Seorang manajer yang melakukan kontrol itu harus sehat jasmani, tidak sedang sakit dan tidak cacat salah satu anggota badannya yang

${ }^{24}$ Al-Qur'an. QS al-Mumtahanah/ 60: 13

${ }^{25}$ Muhammad Bin 'Isa al-Turmudzi. "Jami' Turmudzi”. No. Hadits 1339, Bairut: hlm. 547. Dan Abu Daud as-Sijistani. "Sunan Abu Daud”No. Hadits 4398, Suria: hlm. 1180.

${ }^{26}$ Al-Qur'an. QS az-Zumar/ 39: 9 
menyebabkannya tidak dapat melakukan tindakan control secara sempurna. Hal ini disimpulkan dari firman Allah swt: ${ }^{27}$

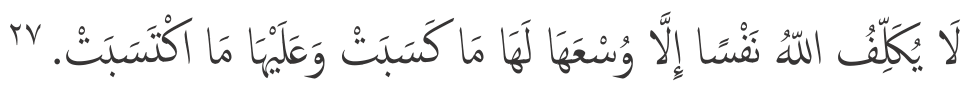

Dalam ayat tersebut, dijelaskan bahwa Allah swt tidak pernah membenani hambanya kecuali selalu dalam batasaan kemampuanhamba tersebut. Berpijak pada kaidah ini, tidak boleh orang yang tidak mampu mengemban amanah controlling menjalankan pekerjaan tersebut.

5) Kekuasaan (authority, السلطة)

Seorang manajer yang melakukan control itu harus memiliki kewenangan penuh secara resmi dalam hal pelaksanaan control tersebut. Hal ini dapat disimpulkan dari pemahaman hadits Rosulullah saw tentang setiap pemimpin akan dimintai pertanggungjawabannya. ${ }^{28}$ Dengan adanya pertanggungjawaban tersebut, secara otomatis pemimpin tersebut memiliki wewenang untuk melakukan controlling, karena hal tersebut merupakan salah satu yang akan dimintai pertanggungjawaban atasnya. Pemahaman yang Lebih jauh, orang yang tidak memiliki wewenang untuk melakukan controlling, tidak boleh melakukannya.

6) Panutan (القدوة)

Seorang manajer yang melakukan control itu harus mampu menjadi panutan yang baik bagi anggota yang dikontrolnya. Hal sesuai dengan firman Allah swt. ${ }^{29}$

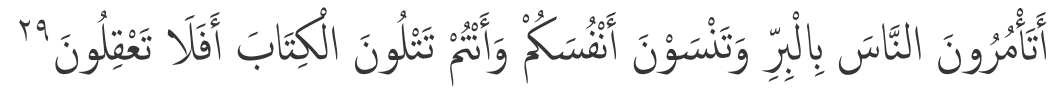

Dalam ayat tersebut, Allah swt mengecam orang-orang yang hanya menyuruh orang lain untuk melakukan kebaikan, sedangkan dirinya sendiri tidak melakukannya. Kegiatan Controling, jika ditinjau dari aspek tujuannya, sejatinya bagian dari aktifitas menyuruh orang lain untuk melakukan kebaikan (sebagaimana yang ditetapkan oleh organisasi yang bersangkutan). Oleh karena itu, seorang manajer harus berusaha sekuat tenaga untuk melaksanakan segala sesuatunya dengan baik dan benar.

${ }^{27}$ Al-Qur'an. QS al-Baqoroh/ 2: 286

${ }^{28}$ Hadits yang dimaksud adalah sabda Rosulullah saw: "

${ }^{29}$ Al-Qur'an. QSal-Baqoroh/ 2: 44 
7) Memiliki integritas (integrity, Fidelity, الأمانة)

Seorang manajer yang melakukan kontrol itu harus amanah, menjalankan tugasnya dengan sebenar-benarnya dan tidak boleh khianat sekecil apapun. Hal ini sesuai dengan firman Allah swt: ${ }^{30}$

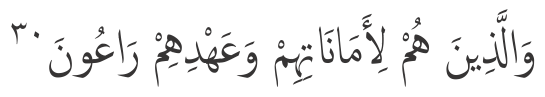

Telah diketahui bersama bahwa kegiatan kontrol adalah bagian dari amanah, oleh karena harus dilaksanakan dengan sebenar-benarnya dan sebaik-baiknya dan tidak boleh dengan sengaja melakukan tindakan khianat sekecil apapun.

8) Positivity, الإيجابية

Seorang manajer yang melakukan kontrol itu tidak hanya cukup mengetetahui kesalahan-kesalahan, tetapi dia harus memberi balasan yang baik bagi yang berprestasi dan memberikan peringatan atau sanksi yang sepadan bagi mereka yang menyimpang. Hal ini sesuai dengan pemahaman terhadap firman Allah swt: ${ }^{31}$

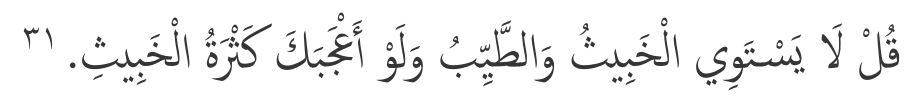

9) Netral (Neutrality, الحياد)

Seorang manajer yang melakukan kontrol itu harus memutuskan dan menetapkan sikap dan segala sesuatunya secara, netral, objektif dan tanpa ada keberpihakan kepada salah satu pihak yang dikontrolnya. Hal ini sesuai dengan firman Allah swt. ${ }^{32}$

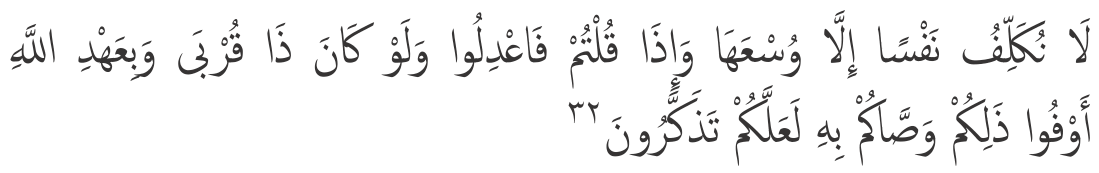

dan firman-Nya: ${ }^{33}$

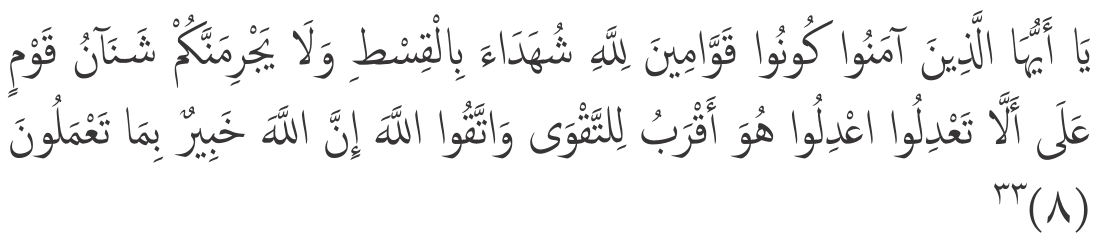

${ }^{30}$ Al-Qur'an. QS. Al-Mukminun/ 23: 8.

${ }^{31}$ Al-Qur'an. QS. Al-Maidah/ 5: 100

${ }^{32}$ Al-Qur'an. QS al-An'am/ 6: 152

${ }^{33}$ Al-Qur'an. QS. Al-Maidah/ 5: 2 


\section{0) Moderasi (Moderation, الرفق)}

Seorang manajer yang melakukan kontrol itu jika ditinjau dari fungsinya dapat dikatakan sebagai seorang hakim. Oleh karena itu, jika manajer tersebut dinilai dari sisi kehakimannya, maka dia harus mampu menjadi sangat tegas namun tidak sampai menjadi bengis apalagi aniaya, dan di saat yang sama, dia juga harus mampu menjadi moderat, namun tidak sampai menjadi lemah apalagi dikuasai oleh pihak lain. Hal ini sesuai dengan sabda Rosulullah saw. ${ }^{34}$

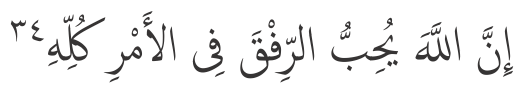

11) Teliti, (Certainty, التيقن)

Seorang manajer yang melakukan kontrol itu harus teliti, memastikan bahwa semua prosedur dan langkah-langkah kontrolnya telah terlaksa dengan baik, dan tidak tergesa-gesa dalam mengambil keputusan sehingga keputusannya menjadi kokoh. Hal ini sesuai dengan firman Allah swt. ${ }^{35}$

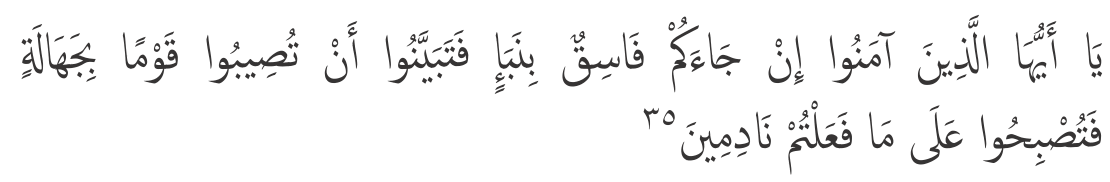

C. Penutup

Dari uraian yang telah dipaparkan tentang studi al-Qur'an dan Hadits mengenai konsep controlling dalam organisasi, maka dapat disimpulkan beberapa hal sebagai berikut:

1. Controlling atau yang di dalam istilah Indonesia bermakna pengendalian, pengawasan atau kontrol, secara sederhana dapat diartikan sebagai suatu proses penyesuaian pergerakan antara organisasi dengan tujuannya.

2. Pengawasan sebagai upaya pengecekan atas jalannya perencanaan (planning) dalam organisasi untuk menghindari kegagalan atau

${ }^{34}$ Muhammad Bin Isma'il Bin Ibrohim Bin al-Mughiroh al-Bukhori. "Shohih al-Bukhori” no. Hadits 6024 Bairut, hlm: 1850. Dan Abu al-Husain Muslim Bin al-Hajjaj Bin Muslim al-Qusyoiri al-Naisyaburi. "Shohih Muslim" no. Hadits 6167, Bairut, hlm: 1512.

35 Al-Qur'an. QS.al-Hujurot/ 49: 6. 
akibat yang lebih buruk. Mengenai faktor ini, al-Qur'an memberikan konsepsi yang tegas agar hal yang bersifat merugikan tidak terjadi. Tekanan al-Qur'an lebih dahulu pada intropeksi, evaluasi diri pribadi sebagai pimpinan apakah sudah sejalan dengan pola dan tingkah berdasarkan planning dan program yang telah dirumuskan semula. 


\section{Daftar Pustaka}

Abu al-Husain Muslim Bin al-Hajjaj Bin Muslim al-Qusyoiri alNaisyaburi, Shohih Muslim, Bairut: Dar Ihya al-Turotsal-'Arobi. Cetakan: Pertama.

Abu Daud as-Sijistani,. Sunan Abu Daud. Siria. Dar al-Kutub. Cetakan: Pertama.

Ahmad Bin Daud al-Mazjaji al-Asy'ari.Muqoddimab Fi al-Idarob alIslamiyah., Jeddah: al-Mamlakah al'Arobiyah al-Su'udiyah, 2000.

Anthony dan Vijay Govindarajan, Management Control System, Mc Clelland Grawhill: Ninth Eition, 1998.

Buchari Alma, Majemen Pemasaran dan Pemasaran Jasa, Bandung: Alfabeta, 1992.

Edward Sallis, Total Quality Management in Education (Manajemen Mutu Pendidikan), terj. Ahmad Ali Riyadi \& Fahrurrozi, Yogyakarta: IRCiSoD, 2011.

Hoetomo, Kamus Lengkap Bahasa Indonesia, Surabaya: Mitra Pelajar, 2005.

M. Dale, Developing Management Skill (terjemahan), Jakarta: Gramedia, 2003.

Muhammad Bin Isma'il Bin Ibrohim Bin al-Mughiroh Al-Bukhori, Shobih al-Bukhori. Bairu:Dar Ibnu Katsir al-Yamamah, Cetakan: Ketiga.

M. Quraish shihab, Tafsir Al-Misbah (Pesan, Kesan, dan Keserasian AlQur'an), Jakarta: Lentera Hati, 2002.

Muhammad Bin 'Isa, Jami' Turmudzi al-Turmudzi, Bairut: Dar Ihya alTurotsal-'Arobi. Cetakan: Pertama. 